Geraden bei Zimmertemperatur in Feldern bis zu 20000 Oe an Proben, die von der Anlaßtemperatur abgeschreckt wurden. Die Thermospannungen der angelassenen und dann abgeschreckten Proben wurden gegen Proben derselben Legierung gemessen, die nach einstündiger Glühung bei $800^{\circ} \mathrm{C}$ abgeschreckt worden sind.

Die Ergebnisse lassen sich durch eine Verschiebung der Fermi-Kante zu kleineren Energien bei der Ausbildung des $K$-Zustandes denten. Eine ausführliche Wiedergabe der Messungen und der Deutung der Versuchsergebnisse wird noch an anderer Stelle veröffentlicht werden.

Physikalisches Institut der Hochschule für Verkehrswesen, Dresden (Divektor: Prot. Dr. habil. H. G. MüLIER)

Eingegangen am 21. Oktober 1957 P. MบTH

1) Thomas, H.: Z. Physik 129, 219 (1951).

\section{Passivity to Corrosion Induced by Chemical Surface Treatments}

Electrode potential measurements have been widely used in studying corrosion and corrosion inhibition ${ }^{1}$ ), ${ }^{2}$ ). Passivity to corrosion induced by various chemical surface treatments which have been developed in recent years for enhancing the intrinsic resistance of metals to corrosion have, however not been studied by this technique. Measurements of the electrode potentials of 1 . zinc which has been given chromate coatings $^{3}$ ) in different baths containing various concentrations of chromic acid and 2. aluminium passivated by various chemical oxidation processes 4 - every one of which is known to improve the corrosion resistance of the metal several times - have been made in $3 \%$ sodium chloride solution and $0.001 \mathrm{~N}$ potassium chloride solution respectively. A few typical results are given in table 1 . The electrode potentials were measured by the Poggendorf method using a Beckman pH meter as the nullpoint indicator. $1^{\prime \prime} \times 1^{\prime \prime}$ specimens were used and the specimens were prepared by a procedure similar to that described by BRASHER ${ }^{5}$ ). It is seen from the above

Table 1. Potential and potential time data on treated and untreated metals

Initial potential vs. sat. cal. electrode at $35^{\circ} \mathrm{C}$ (volts)

\begin{tabular}{|c|c|c|}
\hline $\begin{array}{l}\text { Metal and treatment } \\
\text { given }\end{array}$ & $\begin{array}{l}\text { Potential } \\
\text { volts }\end{array}$ & Form of potential/time curve \\
\hline
\end{tabular}$$
\text { Zinc }
$$

1. Not treated

2. Treated with the solution $\left(200 \mathrm{~g} \mathrm{~K}_{2} \mathrm{Cr}_{2} \mathrm{O}_{7}+\right.$ $6 \mathrm{ml} \mathrm{H}_{2} \mathrm{SO}_{4}$ per litre) for $30 \mathrm{sec}$

\begin{tabular}{c|c}
-0.990 & $\begin{array}{r}\text { Decreases slightly with time } \\
\text { and reaches a steady po- } \\
\text { tential of } 50 \text { millivolts less }\end{array}$ \\
-1.07. & $\begin{array}{c}\text { Decreases slightly more than } \\
\text { untreated metal potential } \\
\text { but remains more negative }\end{array}$
\end{tabular}

Aluminium

1. Not treated

2. Treated by MBV process for $5 \mathrm{mts}$ at 90 to $100^{\circ} \mathrm{C}$

$$
\begin{array}{c|c}
-0.74_{0} & \begin{array}{l}
\text { Falls to a steady potential } \\
\text { near }-0.9 \mathrm{~V} \text { in the course } \\
\text { of a few days. } \\
-1.05_{2}
\end{array} \\
\begin{array}{l}
\text { Rises to initial potential of } \\
\text { untreated aluminium and } \\
\text { falls }
\end{array}
\end{array}
$$

table that passivated zinc has a slightly more negative potential than untreated zinc and the initial potential of treated aluminium is much more negative than that of untreated aluminium. Passivation of a metal surface is, however, usually accompanied by the potential of a metal becoming ennobled. This shift in potential in the negative direction associated with corrosion inhibition in neutral solutions observed above is, therefore, of special interest.

Polarization studies with externally applied e.m.f. at current densities of the order of microamps per sq.cm show that 1 . the cathodic polarization curve of aluminium is rendered much more steep by treatment whereas the anodic polarization curve is practically unchanged and 2 . the anodic as well as cathodic polarization of zinc are enhanced by treatment.

To account for these observations, an equation for the electrode potential of a corroding metal has been derived from the Theory of Electrode Processes by GLASSTONE, LAIDLER and EYRING ${ }^{6}$ ). The final equation comes out to be

$$
-V=\frac{R T}{Z f} \ln \frac{A_{a} X_{2}}{A_{c} X_{1}}
$$

where $A_{a}$ and $A_{c}$ are the total anodic and cathodic areas respectively of the local cells and $X_{2}$ and $X_{1}$ are the specific reaction velocity factors for the anodic and cathodic reactions.

An examination of the equation shows that, when the velocity factors may be taken to be practically unchanged as in the present case, the ratio between the anodic and cathodic areas determines the magnitude and direction of the shift of the electrode potential. The potential shifts observed with zinc and aluminium after treatment, the changes in these potentials with time and the polarization data are all satisfactorily explained in terms of the above equation as arising from changes in the cathodic and anodic areas of the specimen due to treatment and while corrosion is taking place. The present observations and theory developed are in agreement with MEARs mechanism ${ }^{7}$ ) of corrosion inhibition based on the polarization of the local anodes and cathodes. Details are being published elsewhere.

Central Electrochemical Research Institute, Karaikudi, (S. Inaia)

K. S. RAJAGOPALAN and K. S. G. Doss

Eingegangen am. 2. November 1957

1) UHLig, H, H.: Corrosion Handbook. New York: John Wiley \& Sons 1949. - $\left.{ }^{2}\right)$ Evans, U. R.: Metallic Corrosion, passivity and protection. London: Arnold \& Co. 1946. - 3) Pocock, W. E. Metal Finishing, December 1954 and January 1955. - 4) Wernick, S., and R. PInNer: Finishing of Aluminium. Published by Robert Draper Ltd., England 1956. - 5) BrasHer, D. M.: Electro-plating and Metal Finishing, 9, $\left.280(1956) .{ }^{6}\right)$ Grasstone, S., K. J.IAidien and $H$. Eyring: Theory of Rate processes. New York and London: McGraw Hill Book Co. 1941. - 7) Mears, R. B., and H. H. Brown: J. Electrochem. Soc. 97, 75 (1950).

\section{Lumineszenz in der Alumofluorid-Gruppe}

Während zahlreiche Untersuchungsergebnisse über die Lumineszenz einfacher Fluoride wie $\mathrm{CaF}_{2}, \mathrm{ZnF}_{2}$ usw. vorliegen, ist über die Lumineszenz von Verbindungen mit einem komplexen Fluoridanion bisher noch wenig bekannt geworden. Lediglich RANBY and HENDERSON ${ }^{3}$ ) berichten über Magnesium-Silikofluorid, das bei einer Aktivierung mit Ti grüngelb, mit $\mathrm{Ti}+\mathrm{Mn}$ gelb bis rosa fluoresziert. Bei der Prüfung weiterer Fluoridkomplexe auf ihre Verwendbarkeit als Luminophore in Leuchtstofflampen fanden wir, daß bei geeigneter Präparation besonders die Verbindungen der Alumofhorid-Komplexe mit den Elementen der II. Gruppe des Periodischen Systems durch UV zur Fluoreszenz erregbar sind.

Derartige Verbindungen konnten durch Festkörper. reaktion zwischen hoch gereinigtem $\mathrm{AlF}_{3} \mathrm{bzw}$ $\left(\mathrm{NH}_{4}\right)_{3}\left[\mathrm{AlF}_{6}\right]$ und einem Fluorid $\mathrm{MeIF}_{2}(\mathrm{Me} I \mathrm{II}=\mathrm{Mg}$, $\mathrm{Ca}, \mathrm{Sr}, \mathrm{Ba}, \mathrm{Zn})$ bei einstündigem Erhitzen auf 800 bis $900^{\circ} \mathrm{C}$ erhalten werden; der

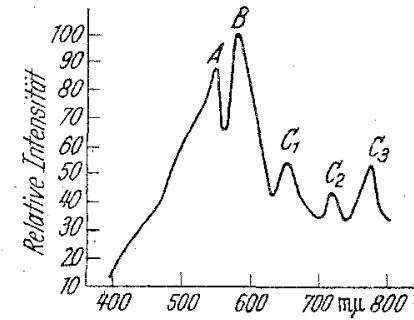

Fig. 1. Spektrale Verteilung der Emission des $\mathrm{Ca}_{3} \mathrm{Al}_{2} \mathrm{~F}_{12} \cdot \mathrm{Ce}, \mathrm{Mn}$ bei Anregung mit $253,7 \mathrm{~m} \mu$. Maxima bei $550 \mathrm{m \mu}(A), 575 \mathrm{mu}(B)$ $x i m a$
$650 \mathrm{~m} \mu\left(C_{1}\right), \quad 720 \mathrm{~m} \mu\left(C_{2}\right)$ $775 \mathrm{~m} \mu\left(C_{3}\right)$, Ordinate: Relative Intensität in willkürlichen

\section{Einheiten}

GlühprozeB wurde in be-

deckten Tiegeln an Luft durchgeführt. Die so erhaltenen Alumofluoride fluoreszieren nicht; Lumineszenzfähigkeit erhalten sie erst, wenn den Ausgangssubstanzen bestimmte Metallsalze - die sog. Aktivatoren - zugemischt werden.

Eingehend wurde bisher nur das Kalzium-Alumofluorid untersucht. Von den zahlreichen Aktivatoren, die geprüft wurden (Mn, Sb, Ti, Ce, Pb, Bi, Ti, Sn), erwies sich nur die Kombination $\mathrm{Ce}-\mathrm{Mn}$ als geeignet; bei einer Aktivatorkonzentration von $10 \%$ Ce und $4 \% \mathrm{Mn}$ wurde bei Anregung mit der Hg-Linie 253,7 mu eine helle gelbgrüne Fluoreszenz (Fig.1) ohne Nachleuchten erhalten.

Messungen der Emissionsintensität in Abhängigkeit vom. Verhältnis $\mathrm{CaF}_{2}: \mathrm{AlF}_{3}$ bei gleicher Konzentration der Aktivatoren $\mathrm{Ce}$ und $\mathrm{Mn}$ hatten zum Ergebnis, daß beim Anregen mit $253.7 \mathrm{mu}$ Maxima der Fluoreszenzintensität bei den Verhältnissen $3: 2$ und $5: 2$ auftraten; diese entsprechen den 